\title{
MY EXPERIENCES IN RECORDING "PANTUN SUNDA"*
}

\author{
Ajip Rosidi
}

A number of pantun Sunda or Sundanese pantun stories were compiled and published at the instruction of K. F. Holle and C. M. Pleyte ${ }^{l}$ at the beginning of this century. But since then little effort has been made to continue their program. To the best of my knowledge, only one pantun story has been written down and published since World War II, the Ratu Bungsu Karma Jaya (The Youngest King Karma Jaya). It was chanted by a pantun bard called Taswan from Kuningan and was transcribed by R. S. Wirananggapati. ${ }^{2}$ However it is said that a man called Mochtar Kala inherited a collection of "Pantun Bogor" from his ancestors, which were written down in the pre-World War II period, but only part of one pantun story has been published, the Dadap Malang di Sisi Simandiri. ${ }^{3}$ This scarcity of published pantun explains why the Sundanese themselves need to refer to the material published by Holle and Pleyte. (For instance, Drs. Atja corrected Pleyte's transcription of the Lutung Kasarung as written down by Argasasmita. ${ }^{4}$ )

* Pantun Sunda is a type of performance in West Java in which a musical instrument called pantun, a kind of kecapi (a stringed instrument played by plucking) is used. To the accompaniment of the kecapi, and sometimes also of the flute, the tarawangsa (a stringed instrument played like a violin), or other instrument, the pantun bard narrates a lengthy story. The story usually describes the adventures of a prince of Pajajaran, a pre-Islamic kingdom which existed in West Java up to the beginning of the sixteenth century. The verse narration is chanted the whole night through, starting around 7:30 p.m. and ending just before daybreak. For more details about the pantun, see F. S. Eringa, "Loetoeng Kasaroeng, een mythologisch verhaal uit West Java," Verhandelingen van het Koninklijk Instituut voor Taal-, Land-, en Volkenkunde, VIII (1949), pp. 1-7.

1. For some examples, see the following items transcribed and edited by C. M. Pleyte: "'Raden Moending Laja di Koesoema,' Een oude Soendasche ridderroman," Tijdschrift voor Indische Taal-, Land- en Volkenkunde, XL (1906); "De ballade 'Njai Soemoer Bandoeng, "I" Verhandelingen van het Batavia Genootschap van kunsten en Wetenschappen, LVIII (1910); "De lotgevallen van 'Tjioeng Wanara,"" ibid.; and "De legende van den 'Loetoeng kasaroeng,' Een gewijde sage uit Tji-řrebon," ibid.

2. R. S. Wirananggapati (trans.), Ratu Bungsu Karma Jaya (Jakarta: Dana Guru, 1961) (with an introduction by $R$. Satjadibrata) .

3. Rakean Mindakalangan, Dadap Malang sisi Tji Mandiri (Bogor: Mangle, 1964), passim. In this publication Mochtar Kala uses the name Rakean Minda Kalangan. Upon examination of the manuscript one notes that it contains many words not known to the Sundanese until after the Japanese occupation. The structure also differs from that of pantun in general: among other things, there are few of the repetitions so characteristic of folklore.

4. The manuscript by Argasasmita, an official in charge of coffee storehouses at Tawanglarang, is written in Javanese characters, and is kept in the Jakarta 
Many changes are taking place at an ever increasing rate in sundanese society: The society in which pantun used to be an important manifestation of art and ritual is disappearing. Urbanism exercises a growing influence on the life of the Sundanese, and consequently their view of pantun and the significance of pantun in their lives have been continually changing. Under the influence of a spreading rational, economical and practical outlook the ritual, religious and magical significance of the pantun is declining. No longer a ritual related to the life cycle of man, it has become merely a form of recreation. Moreover as a form of recreation the pantun is particularly adapted to a shrinking traditional rural life. Its close relationship with the ritual of rice-planting, indicated by Eringa, 5 is clearly evident; performances are held during the nights after the harvest until work on the paddy fields has to be resumed--the season when the peasants do not work during the daytime.

As Sundanese society has had to adjust to the rhythms of bureaucratic life the feeling has grown that performances which last all night long such as pantun-chanting and wayang golèk (shadow puppet plays using wooden three-dimensional puppets traditional to West Java) shows are no longer appropriate. Efforts have therefore been made to shorten the time of wayang golèk shows (initiated by R. O. Partasuanda) and of pantun-chanting (initiated by Beton, alias Wikatman) to a few hours so as not to interfere with work on the following day.

Even as a form of recreation, the pantun is not tuned to the times; it is not lively and dynamic enough, it is too serene. The audience has to listen quietly and attentively to the story and the melody as chanted by the bard; these have come to be seen as monotonous and even boring. Most Sundanese are more attracted to 1 ivelier art forms--wayang golek, réog (comical review), musical bands and so forth. Particularly since transistor radios have become a familiar feature even in remote villages, the pantun has been increasingly abandoned. The only pantun-lovers are the older people who still feel a certain emotional attachment to ancient stories or perhaps just to the past. The bards remaining are generally of advanced age; there are very few young people who are interested in learning from them. Thus the number of pantun bards is constantly decreasing, and they are usually found only in remote villages. Most of the pantun bards living in the cities have compromised the art by adding new elements such as kawih (a kind of Sundanese song), pasinden (female singer), and even gamelan music to performances of the stories. Thus, if a pantun presentation originally focused on the story chanted by the bard, it has now become a form of amusement at which people listen to the female singers. The pantun bard offers his narration only every now and then, and he usually merely tells jokes. These pantun bards have been engaged by the Bandung radio network to give weekly performances so that pantun bards living in remote villages where transistors have been introduced are now following this bad example.

Because of this situation I came to believe that Sundanese pantun and other folklore should be recorded immediately. If we fail to do

Central Museum (Sundanese manuscript No. 113). This manuscript was retranscribed by Drs. Atja, using the Latin alphabet, but it is not yet published. He reported that the text published by Pleyte contained errors of transcription.

5. Eringa, "Loetoeng Kasaroeng," pp. 17-19. 
so, then quite probably this kind of art will soon be 1ost. Initially it was hoped that the government would conduct the program of recording, but because of current unfavorable economic conditions in the country, that proved illusory. Finally a program of sorts was started with assistance received from Professor Dr. A. Teeuw through the Royal Institute for Philology, Geography and Ethnology in Leiden.

The first problem was contacting a pantun bard. There was no institute which could give us information concerning pantun bards existing anywhere in West Java. Not even the Regional Office for Cultural Development could give us much assistance. They had issued cards for artists ${ }^{6}$ but very seldom were they interested in pantun bards. I requested the chief of the Bandung office to help compile a list of pantun bards throughout West Java by issuing forms to be filled out by the Office for Cultural Development in each kabupatèn (regency), but of the twenty-six kabupaten offices in the province, only five filled out and returned the forms, and after examining these forms I felt there was no guarantee that they had been filled out accurately. From other sources I was able to compile a list of pantun bards who were not mentioned in the lists of the kabupatèn offices.

Thus it was necessary to gather information directly--to examine every name or piece of information received. And there was no guarantee that the names of people reported actually were pantun bards since many Sundanese no longer know what pantun really means. Often a person thought to be a real pantun bard chanted in the "new style," which was of no use for our research purposes.

On the other hand, there were old pantun bards who stubbornly refused to come to Bandung or Jakarta for recording. And there were those who refused to be recorded at all. We had to go and meet them ourselves, or send somebody far into the remote areas to do the recording. Results were not always satisfying. We were also handicapped by the limited ability of the persons in charge of handiing the tape recorder. Very often we had to repeat the recordings entirely.

After recording, various problems arose in the process of transcription; the narrations were often in dialects which varied considerably from the language generally spoken. Many words were difficult to grasp or were disconnected from one another; many words were distorted or no longer recognizable. It would have been advisable, of course, to contact the pantun bard again after completing the transcription, in order to check its accuracy word for word. However, this was impractical and at present quite unfeasible. To verify a single pantun story (one full night's recording) would take several days' consistent work. Because of other commitments, it was not possible to make such visits to the pantun bards' villages in the remote areas; nor was it possible to have the pantun bards come to Bandung for a few days. The pantun bards also had responsibilities in their villages. We would have had to pay them to come, which was beyond the means of our project.

6. The Office for Cultural Development in many kabupatèn and cities in Java issues compulsory "artists cards" to artists living in the respective areas. Artists not in the possession of such a card are not permitted to display their talents. To obtain such a card the artist has to pay a certain fee and for performances he has to pay another fee to the official in charge at the Office for Cultural Development who inspects the cards. 
We thus faced a real dilemma; either to collect as many pantun stories as possible, although very much aware of the many unavoidable faults, or to achieve the best possible results on fewer stories--which would be very time consuming and would require more funds and more intensive, concentrated work. Being an amateur in the field, I could not follow the second method. There should be someone else who would be prepared to take full responsibility for this job. But it is difficult to find people willing to consistently do a job which may be boring, requiring full nights without sleep, followed by listening to the recording while working on the transcriptions, over and over again, day after day. . . Moreover, we have learned that the pantun bards themselves often cannot clarify the meaning of the words used. Generally they only memorize the words or sentences without understanding their meaning.

Because of difficulties in obtaining accurate information concerning pantun bards in the kabupatèn, the original program of making recordings systematically from kabupatèn to kabupatên could not be implemented. As of now recordings have been conducted with two pantun bards from the kabupatèn of Kuningan, one from the kabupatèn of sumedang, five from the kabupaten of Bandung, two from the kabupaten of Subang, one from the kabupaten of Purwakarta, two from the kabupaten of Sukabumi, and two from the kabupaten of Lebak (Baduy).

We recorded at least one story from each pantun bard. If he was a good chanter, he was asked to record a few other stories, particularly those of a specific nature or those which had not been recorded previously. Twenty-eight stories have been recorded and fourteen have been published among the eighteen stories which have been transcribed. Not all of the stories recorded were considered worthy of transcription, nor were all transcriptions worthy of publication.

Some general preliminary conclusions may be drawn from the recordings and transcriptions completed. Pantun bards from the kabupaten of Bandung are the most easily influenced by the radio-broadcast style epitomized by Beton.

The influence of radio broadcasts is also discernible on a number of pantun bards from other kabupatèn, with the exceptions of those from the Baduy area who reject such influences. The pantun in the Baduy community, in fact, still has a sacred function.

There is a remarkable similarity of pattern and phraseology in the pantun stories, especially between those from Kuningan, Baduy and Sukabumi, yet geographically these kabupatèn are in the most eastern and the most western parts of West Java respectively, separated by many other kabupatèn.

In spite of similarities of pattern and phraseology, particularly in magic formulae, certain differences exist which are indicative of local variations and of the individual characteristics of the pantun bards. In the pantun stories of $\mathrm{Ki}$ Aceng Tamadipura and $\mathrm{Ki}$ Kamal, for example, certain parts are the product of personal experience. Thus, Ki Aceng Tamadipura's tales clearly manifest the influence of his early education in a madrasah (religious school). Local variations are also evident in the pantun melodies.

The pantun bards interviewed had differing opinions as to which pantun are sacred. Even bards from the same areas disagreed. Experts 
generally agree that Lutang Ka Sarung is the most sacred story. But, Ki Sajim (from Lebak, Baduy) thinks it is quite ordinary and on the same level as the story of Paksi Köling and of Buyut Orenyeng. The tale which he regards as sacred is that of Gajah Lumantang, a story which is unknown in areas outside Baduy. ${ }^{7}$ There is no single story which is considered sacred everywhere throughout the "pantun area."

The above conclusions suggest that in traditional society pantun is not merely a memorization of inherited material, but has room for local and individual variations. If such an openness to influences from outside is present, to what extent do the original elements persist? They may persist in the Baduy community because it has been relatively closed from outside influences from the time it separated itself from Pakuan Pajajaran. For example, if we compare the melody chanted by the Baduy pantun bard, Ki Sajim, with that of Ki Asom from Subang Purwakarta there are striking differences. It may be that the style of the Baduy pantun bards is closer to the original Pajajaran form than to contemporary forms.

It is very discouraging that our people, even the Sundanese, seem to have no interest in the publication of pantun. In a developing country where people are infatuated with modernization, the recording of folklore is considered irrelevant to the demands of contemporary 1ife. Certain experts and institutes have shown some interest in this program, but financial assistance cannot be expected of them. Due to existing conditions for social scientists in Indonesia and the financial incompetence of our scientific institutes, the project has submitted its publications to them free of charge, or at a minimum charge.

In my opinion, in developing countries such programs can only be realized through international cooperation. Full-time workers should be paid salaries which could provide them with the sense of security which is essnetial to do their jobs properly.

In addition, adequate equipment is necessary. Recording should be done in a closed room to prevent the interference of outside noise, and should be executed by experts. The final recordings should be preserved properly at a well-controlled temperature. In our project these precautions were just dreams waiting to be realized. In actuality, recordings were conducted in a house I rented in Bandung with walls of matted bamboo, so that all the voices of peddlers passing by were also included in the recordings. 8

A project as outlined above could be used as a pilot project for folklore-recording in other areas. Ideally it would be executed by people who are native to the respective areas, because a certain emotional attachment is necessary so that the job is done with enthusiasm, not by people easily bored. Natives would also be able to overcome various technical difficulties related to the cultural background, beliefs and other characteristics of the particular areas.

7. The story was published by J. J. Meijer in "Badoeische Pantunverhalen," Bijdragen tot de taal-, land-, en volkenkunde van Nederlandsch-Indië, XL (1891), p. 45.

8. In Indonesian cities food-venders try to sell their wares along the streets by shouting or clattering on plates or other objects. Each kind of food is indicated by a particular sound. 
Such a recording and publication program should be intensive and cover a rather long period of time so that as many samples as possible are collected (simultaneously useful as documentation) and data for diachronic comparisons are provided. Because the field of pantun embraces music and phraseology there should be close cooperation between experts in these fields. The results of the transcription would be useful not only to philologists or lexicographers, but also to students of ancient Sundanese beliefs, tradition, law, architecture and so forth.

\section{Appendix \\ List of pantun stories recorded and published by the Research Project of Sundanese Pantun and Folklore}

There are thirty titles of pantun stories recorded by Eringa, most of which still belong to the repertoire of pantun bards contacted for recording by the Research Project of Sundanese Pantun and Folklore. The research emphasized the recording of stories never mentioned earlier, in addition to those already recorded and published. To date the following pantun stories have been recorded, a number of which have been transcribed and of which a smaller number have been pub1 ished.

1. DEMUNG KALAGAN by Ki Kamal (Kuningan), transcribed and published (series no. 1);

2. LUTUNG LUTIK by Ki Kamal (Kuningan), transcribed;

3. KEMBANG PANYARIKAN by Ki Kamal (Kuningan), transcribed;

4. LUTUNG KASARUNG by Ki Kertawiguna (Kuningan), not to be transcribed or published. (E)*

5. MUNDINGLAYA DI KUSUMAH by Ki Aceng Tamadipura (Sumedang), transcribed and pub1ished (series no. 2); (E)

6. SRI SADANA or SULANYANA by Ki Aceng Tamadipura (Sumedang), transcribed and published (series no. 3); (E)

7. RINGGIT SARI by Ki Aceng Tamadipura (Sumedang), transcribed;

8. PANGGUNG KARATON by Ki Aceng Tamadipura (Sumedang), transcribed and published (series no. 9); (E)

9. BUDAK MANJOR by Ki Aceng Tamadipura (Sumedang), transcribed and published (series no. 12); (E. Ko Manjor and Nyi Gendruk)

10. CIUNG WANARA by Ki Aceng Tamadipura (Sumedang), transcribed but unfinished due to failure of recording (damaged); (E)

11. NYI SUMUR BANDUNG by Ki Enjum (Bandung), transcribed and published (series no. 4); (E)

* Stories mentioned in Eringa's list are indicated here with (E). 
12. SENJAYA GURU (version I) by Ki Enjum (Bandung), transcribed but may not be pub1ished;

13. SENJAYA GURU (version II) by Ki Enjum (Bandung), transcribed but not yet published;

14. RANGGA KATIMPAL by Ki Otang (Bandung), not to be transcribed or pub1ished;

15. MUNDING WANG I by Ki Hamami (Bandung), not to be transcribed or published;

16. CIUNG WANARA by Ki Subarma (Bandung), transcribed and published (series no. 14); (E)

17. MUNDING KAWATI by Ki Atma (Subang), transcribed and pub1ished (series no. 10);

18. GANTANGAN WANGI by $\mathrm{Ki}$ Asom (Subang), transcribed;

19. JAYA MANGKURAT by Ki Nasir Supandi (Purwakarta), may not be transcribed or published;

20. PERENGGONG JAYA by Ki Samid (Sukabumi), transcribed and published (series no. 6);

21. RADEN TANJUNG by Ki Samid (Sukabumi), transcribed and published (series no. 8);

22. BADAK PAMALANG I by Ki Samid (Sukabumi), transcribed and published (series no. 10); (E)

23. BADAK PAMALANG II by Ki Samid (Sukabumi), transcribed and published (series no. 10A); (E)

24. LUTUNG KASARUNG by Ki Sajin (Lebak, Baduy), transcribed and published (series no. 13); (E) this version shows marked differences;

25. BUYUT ORENYENG by $\mathrm{Ki}$ Sajin (Lebak, Baduy), not yet transcribed;

26. PAKSI KELING by Ki Tanci (Lebak, Baduy), not yet transcribed; (E)

27. DALIMA WAYANG by Ki Ating (Tepalpangjang, Sukabumi), not yet transcribed;

28. RADEN MANGPRANGJAYA DI KUSUMAH by Ki Asom (Subang);

29. BIMA MANGGALA by Ki Ating (Telolparjang, Sukabumi), not yet transcribed;

30. LIMANJAYA MANTRI by Ki Asom (Subang), not yet transcribed. 